No $2003-13$

September

How Different is Eastern Europe? Structure and determinants of location choices by French firms in Eastern and Western Europe

Anne-Célia Disdier Thierry Mayer 


\title{
How Different is Eastern Europe? Structure and determinants of location choices by French firms in Eastern and Western Europe
}

\author{
Anne-Célia Disdier
}

Thierry Mayer

No $2003-13$

September 


\section{Table of Contents}

1. INTRODUCTION

2. UNDERLYING THEORY AND RELATED EMPIRICAL LITERATURE 9

3. ECONOMETRIC MODELS 11

4. Data 13

4.1. The dependent variable: Location choice . . . . . . . . . . . . . . . . . . . . . . . . 13

4.2. The independent variables . . . . . . . . . . . . . . . . . . . . . 13

5. Results 19

5.1. Results of the estimations led with conditional logit model . . . . . . . . . . . . . 19

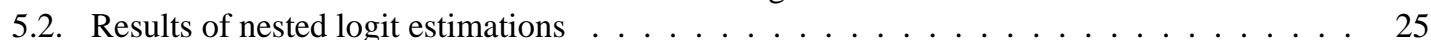

6. Conclusion 25 


\section{HoW Different is EASTERn Europe? STRUCTURE AND DETERMINANTS OF LOCATION CHOICES BY FRENCH FIRMS IN EASTERN AND WESTERN EUROPE}

\section{SUMMARY}

Theoretical analysis of location choices has recently known a renewal with contributions of the new economic geography. Besides traditional determinants, positive externalities generating agglomeration effects are taken into account in these contributions. Central and Eastern European Countries (CEECs) represent an interesting case study. Because of the enlargement process of the European Union (EU) to these countries, changes in agglomeration and dispersion forces could be expected in the next decades in Eastern and Western Europe. Assessing these forces will offer an idea of the potential evolution in the economic geography of Europe.

We focus in this paper on the determinants of location choices of French multinational firms in Europe and investigate the relevance of an East-West structure. Our sample includes 1843 location choices in 19 countries over the period 1980-1999. This relatively large time period enables us to highlight the impact of the transition process, and of the reintegration of CEECs into the world market.

Determinants of location decisions are empirically estimated first with a conditional logit model, and second with a nested logit model. Both models with a qualitative endogenous variable are adapted to the study of the location decisions of a firm, which are discrete choices made among different alternatives. However, location choices are very likely to have a nested structure, and the nested logit model allows to report the two steps of the decisions and to analyse the level (regional and/or national) of influence of each determinant.

Our results suggest there might be important differences between the two regions of Europe concerning these determinants. Noticeably, agglomeration effects are less strong in CEECs than in EU countries. This seems to suggest the presence of a stronger competition between firms in these countries. Another interpretation could be found in forward and backward linkages. Furthermore, quality of institutional framework has also a stronger impact on location decisions in CEECs than in EU countries. Besides, GDP, which offers a measure of the potential demand, has a weaker influence for EU countries than for CEECs. Local markets seems an important determinant in the recent rise of inward investment in CEECs. Results also confirm that these choices are geographically nested. French firms first choose a region (Eastern or Western Europe), and then a country within the region chosen. However, the relevance of this East-West structure seems to decrease as the transition process advances, and this decrease is statistically significant over the period considered. 


\begin{abstract}
We study in this paper the determinants of location choices of French multinational firms in Eastern and Western Europe. Our sample includes 1843 location choices in 19 countries over the years 1980 to 1999. Our results suggest there might be important differences between the two regions of Europe concerning these determinants. Noticeably, agglomeration effects are less strong in CEECs than in European Union countries. Location decisions are significantly and positively influenced by the institutional quality of the host country. Our work also investigates whether investors consider Western Europe and Eastern Europe as two distinct groups of potential host countries. We confirm the relevance of an East-West structure in the country location decision and also show that the relevance of this structure decreases as the transition process advances.
\end{abstract}

JEL classification: F23, R3

Key words: Foreign direct investment, location choice, conditional logit, nested logit, European Union, Eastern Europe. 


\section{STRUCTURE ET DÉTERMINANTS DES CHOIX DE LOCALISATION DES FIRMES MULTINATIONALES FRANÇAISES EN EUROPE DE L'EST ET EN EUROPE DE L'OUEST}

\section{RÉSUMÉ}

Les développements de la nouvelle économie géographique ont récemment permis un renouveau de l'analyse théorique des choix de localisation, en introduisant, outre les déterminants traditionnels, des externalités positives favorisant l'agglomération des activités. Les pays d'Europe centrale et orientale (PECO) représentent un cas d'étude interessant. Du fait du processus d'élargissement de l'Union Européenne (UE) à ces pays, des changements dans les forces d'agglomération et de dispersion peuvent être attendus en Europe au cours des prochaines décennies. L'évaluation de ces forces peut offrir une idée de l'évolution potentielle de la géographie économique de l'Europe.

Dans cet article, nous concentrons notre analyse sur les déterminants des choix de localisation des firmes multinationales françaises en Europe et examinons si les investisseurs considèrent l'Europe de l'Est et l'Europe de l'Ouest comme deux groupes distincts de pays potentiels d'accueil. Notre échantillon comprend 1843 choix de localisation dans 19 pays au cours de la période 1980-1999. Cette relativement longue période nous permet de mettre en évidence les effets du processus de transition et de la réintégration des PECO dans l'économie mondiale.

Les déterminants des décisions de localisation sont empiriquement estimés premièrement avec un modèle logit conditionnel, et deuxièmement avec un modèle logit hiérarchisé. Ces deux modèles à variable endogène qualitative sont adaptés à l'étude des décisions de localisation d'une firme, décisions qui sont des choix discrets entre plusieurs sites. Le modèle logit hiérarchisé permet de prendre en compte les deux étapes de la décision de localisation et d'analyser le niveau (régional et/ou national) d'influence de chaque déterminant.

Nos résultats suggèrent l'existence d'importantes différences entre ces deux parties de l'Europe concernant ces déterminants. En particulier, les effets d'agglomération sont moins forts dans les PECO que dans les pays de l'UE. Ceci semble suggérer la présence d'une plus forte compétition entre les firmes dans ces pays. Une autre interprétation peut être trouvée au niveau des liens amont et aval. Les décisions de localisation sont également positivement et significativement influencées par la qualité de l'environnement institutionnel du pays d'accueil. De plus, le PIB qui fournit une mesure de la demande potentielle, a une influence plus faible pour les pays de l'UE que pour les PECO. La taille des marchés locaux semblent être un déterminant important de l'augmentation récente des investissements étrangers dans les PECO. Les résultats confirment enfin que ces choix de localisation sont géographiquement hiérarchisés. Les firmes françaises choisissent d'abord une région (Est ou Ouest de l'Europe) puis un pays au sein de la région retenue. Toutefois, la pertinence de cette structure "Est-Ouest" tend à décroître au fur et à mesure de l'avancée du processus de transition et cette décroissance est statistiquement significative sur la période considérée. 


\section{RÉSUMÉ COURT}

Nous étudions dans cet article les déterminants des choix de localisation des firmes multinationales françaises en Europe de l'Est et en Europe de l'Ouest. Notre échantillon inclut 1843 choix de localisation dans 19 pays au cours de la période 1980-1999. Nos résultats suggèrent l'existence d'importantes différences entre ces deux parties de l'Europe. En particulier, les effets d'agglomération sont moins forts dans les PECO que dans les pays de l'UE. Les décisions de localisation sont également positivement et significativement influencées par la qualité de l'environnement institutionnel du pays d'accueil. Notre travail analyse en outre si les investisseurs considèrent l'Europe de l'Est et l'Europe de l'Ouest comme deux groupes distincts de pays potentiels d'accueil. Nous confirmons la pertinence d'une structure de type "EstOuest" dans le choix de localisation et montrons que la pertinence de cette structure tend à décroître au fur et à mesure de l'avancée du processus de transition.

Classification JEL : F23, R3

Mots Clefs : investissement direct étranger, choix de localisation, logit conditionnel, logit hiérarchisé, Union Européenne, Europe centrale et orientale. 


\title{
HoW DifFERENT IS EASTERN EuRope? STRUCTURE AND DETERMINANTS OF LOCATION CHOICES BY FRENCH FIRMS IN EASTERN AND WESTERN EUROPE ${ }^{1}$
}

\author{
Anne-Célia DISDIER ${ }^{2}$ \\ Thierry MAYER ${ }^{3}$
}

\section{INTRODUCTION}

Since the beginning of the 1990s, Central and Eastern European Countries (CEECs) have attracted a growing amount of foreign direct investments (FDI). Prospects of enlargement of the EU to those countries have indisputably increased this phenomenon, triggering fears in the public opinion of current EU member countries about the whole enlargement process ${ }^{4}$.

We investigate in this paper whether the determinants of location decisions by foreign investors in Eastern Europe are similar to those explaining location choice in Western Europe. We consider investments by French multinational firms in EU countries and in CEECs over the period 1980-1999, and analyze the geographic structure of this choice. We compare the determinants of location choice in the two parts of Europe to assess the existence of a possible "East West divide" in the decisions of foreign investors, and its evolution as the transition process proceeds and the enlargement gets closer.

The impact of the transition process for CEECs has been the subject of investigation of a number of papers analyzing the trade patterns evolution. From those contributions, we learn that trade flows both emanating from Eastern Europe countries and going to those countries have been subject to vast and rapid changes in the early years of transition. An important early work carried by Baldwin (1994) found that in 1989, bilateral trade flows between CEECs and EU countries were far below their "normal" levels. However, recent work (Fontagné et al., 1999; Nilson, 2000) shows that this trade potential seems already exhausted in the mid nineties, emphasizing the very rapid shift in trade patterns of those countries.

We want in this paper to investigate whether the changes in inward FDI in those countries have followed the same "fast return to normal" pattern. If this is to be the case, we would expect to find the following: In

1. This paper is part of a research programme "Optimum Choice of Exchange-rate Regime for the Accession Countries: Cost and Benefit Analysis of EMU Membership”, ACE Phare Project N ${ }^{\circ}$ P98 $1061 \mathrm{R}$. We thank participants at the European Economic Association Meetings (EEA2002), and at the Third International Conference on Public Economics of the Association for Public Economic Theory (PET 2002) for helpful comments. We are also grateful to seminar participants (CEPII, ACE PHARE Project N P98 1061 R final workshop, and TEAM-University of Paris 1) for fruitful discussions.

2. TEAM, University of Paris I (adisdier@univ-paris1.fr).

3. University of Paris XI, also affiliated at CEPII, CERAS, and CEPR (tmayer@univ-paris1.fr).

4. This topic of East-West FDI location is likely to even more important in the newly enlarged Europe as FDI inflows in CEECs are expected to experience a new major increase. Based on the experience of previous enlargements, a recent policy paper by the CEPR (2002) reports estimates of a (temporary) doubling of FDI inflows in those countries in the wake of enlargement. 
the early days of transition (and even more so before the beginning of the transition process), the distinction between Eastern Europe and Western Europe countries should be very important in the location choice of foreign investors, but, as the transition process goes on, investors should consider countries more and more independently from the fact that they belonged or not to the Eastern bloc. We use a nested logit modelling of location choices of French firms in order to empirically assess if this expectation is verified.

The existing literature on FDI location decisions in CEECs is rather scarce. Meyer (1995)'s survey offers an overview of FDI in CEECs during the first part of the 90's. Conclusions of this study show in particular that services sectors have received substantial FDI, while manufacturing has attracted most of capital inflows. The main attracting factor of CEECs according to this paper is the local market. In contrast, production costs advantages do not appear as a dominant motivation for investing. Political, economic and legal environment is also a key determinant for foreign investors. The importance of those institutional determinants is confirmed by Bevan and Estrin (2000). Besides, their results suggest that announcements of progress in EU membership has a positive and significant influence on FDI inflows. Using a survey of senior managers of 117 western manufacturing, Lankes and Venables (1996) study in more detail the characteristics of FDI. Determinants of distribution and local markets oriented FDI on the one hand, and export oriented FDI on the other hand prove to be different: As expected, proximity to consumers is dominant in the first case, whereas factor costs advantages of CEECs play a crucial role in the second case. Lankes and Venables (1996) also highlight a link between control mode and others inflows determinants: Investors with an export-oriented strategy favor wholly-owned ventures, while investors intending to serve the local market are more inclined to have a local partner. Pennings and Altomonte (2003) recently studied how uncertainty might affect the decision of investment with an empirical application to CEECs. Their results suggest that the investment probability is negatively and significantly influenced by uncertainty. This effect of uncertainty comes through its effect on expected profitability, rather than through the option value of delay in investment.

The remainder of the paper is structured as follows: The underlying theoretical framework and related empirical literature are described in section 2., the econometric models used in the empirical application are presented in section 3.. Section 4. describes the data. Empirical results are given in section 5., and section 6. concludes.

\section{UNDERLYING THEORY AND RELATED EMPIRICAL LITERATURE}

Recent theoretical work often grouped under the name of New Economic Geography (NEG) have contributed to a renewal of the analysis of location choices (for a very complete overview of this theoretical field, see Fujita et al. 1999, Neary 2001 and Fujita and Thisse 2002 for instance).

Endogenous agglomeration of activities is a central tenet of this new framework, the observed level of clustering of firms being the result of a trade-off between several centripetal (agglomeration) and centrifugal (dispersion) forces. In the traditional trade framework, agglomeration of industries is a by-product of specialization of countries along the lines of comparative advantages dictated by exogenous differences. In contrast, agglomeration results in NEG models from the interaction of increasing returns to scale and transport costs which causes firms to concentrate production in a single plant and located this plant near final demand. The consumers have in turn an incentive to co-locate with firms essentially because the agglomeration of production bids up factor prices and lowers the price index through the savings on transport 
costs when living where the largest number of varieties are produced. Those pecuniary externalities trigger a circular process of agglomeration which is (briefly sketched) the essence of the Krugman (1991) model ${ }^{5}$.

Following this theoretical framework, location choice of individual firms will essentially tend to be determined by market access and production costs. In NEG models, investors are repelled by areas where the cost of production is high and wish to locate in central places which guarantee a good access to the different markets targeted. ${ }^{6}$ This market access effect can be summarized in the "market potential" presentation of firms profits presented in Head and Mayer (2002). An important element for our purpose is that in an imperfect competition model, the attractiveness of a country is not only a function of market access but also depends on the intensity of competition in this country. In places where perceived demand is high, there will also in general be a large number of producers, which produce a dispersion force taking the form of rising competition on the goods market as firms concentrate in the same area.

To summarize, NEG predicts that location choice should be positively influenced by the size of perceived demand and negatively associated with production costs and local competition intensity (the number of firms being the usual proxy for this effect). Note that the recent advances in the theoretical analysis of Foreign Direct Investment (see Markusen and Venables, 1998 for instance) offer very related insights in sometimes very close modelling (Brainard, 1993). The literature on FDI indeed offers similar predictions about a very specific location choice: Producing at home (and exporting) against producing abroad (through FDI) which in many respect is simply a particular case of the NEG predictions.

There are however other types of (non pecuniary) externalities that are (voluntarily) left aside by NEG theory but can nevertheless be important in the real world. Knowledge spillovers are certainly the most obvious mechanisms nowadays that can produce an additional force towards agglomeration of industries. Individual firms can be attracted by areas where other producers are numerous because of a positive impact on their productivity through spillovers. As a consequence, the overall impact of the location of competitors on the location choice is ambiguous: The existence of spillovers might give incentives for clustering with other firms of the industry, whereas increased competitive pressures leads firms to look for locations where the number of competitors is low. Whether one force dominates the other is essentially an empirical matter.

The existing body of individual firm level empirical studies of location choices by foreign investors tend to support the dominance of agglomeration forces over dispersion ones. This is observed at the national level (Devereux and Griffith, 1998, Smarzynska $\left.{ }^{7}, 1999\right)$, and at a sub-national level (Head et al., 1995 and 1999 , Hansen, 1987, Head and Ries, 1996, Guimarães et al., 2000, Crozet et al., 2003). The same result holds for location choices of French multinationals in EU regions at the end of 1993 (Ferrer, 1998), and in location decisions of Japanese firms in Europe at a national and regional level (Mayer and Mucchielli, 1999).

5. Note that very similar mechanisms of backward and forward linkage take place between firms linked through input-output relationships. Intermediary goods producers want to locate near the demand for their products, and final goods producers gain from this presence of a large local pool of inputs; as Venables (1996) first stressed.

6. In general equilibrium, central places attract a lot of firms which of course bids production costs up. Thus in equilibrium - when firms do not have any more incentive to move - wages are a (positive) function of market access (see Fujita et al. 1999 for a theoretical exposition and Redding and Venables (2000) for an empirical application of this relationship). Here we however precisely study the adjustment to equilibrium where individual firms choose their location and this decision will be negatively associated with production costs and positively with market access.

7. Using a probit model, Smarzynska (1999) examines the impact of intellectual property rights on investment decisions of multinationals in transition economies. 
Implications of these theoretical and empirical results are important. First, if the probability for a location to attract FDI is an increasing function of the existing presence of multinational firms, the spatial pattern of activity will consist of cumulative clustering of industries ending up in a strong core-periphery pattern. Second, promotion policies could be used by authorities in order to reduce or trigger these cumulative agglomeration effects, thereby giving rise to important tax competition issues ${ }^{8}$. Third and perhaps more important, the relative strength of agglomeration and dispersion forces depend crucially on the level of transaction costs faced by investing firms when shipping their goods to various markets in the area where they have to choose a location. In the perspective of the enlargement of the EU to a large number of CEECs, forces of agglomeration and dispersion need to be assessed in order to get an idea of the potential change in the economic geography of Europe once this group of country is given a much improved access to the Western Markets (and vice versa).

\section{ECONOMETRIC MOdelS}

We use in this paper information about individual firms location choices over a set of $19 \mathrm{EU}$ and Eastern European countries. The most used econometric modelling technique for this type of problem is the conditional logit model proposed by McFadden (1984). To the extent that each location decision is a discrete choice made among several alternatives, this model with a qualitative endogenous variable is particularly adapted.

Suppose $J=(1, \ldots, j, \ldots, n)$, the set of possible location countries. Each location offers a profit $\pi_{j}$ :

$$
\pi_{j}=U_{j}+\epsilon_{j}
$$

where

$$
U_{j}=b X_{j}
$$

With $U_{j}$ a function of observable characteristics $\left(X_{j}\right)$ of location $j, b$ the vector of coefficients to be estimated, and $\epsilon_{j}$ the unobservable advantage of location $j$.

Location $j$ is chosen by a firm if it allows this firm to obtain a higher profit than the ones obtained in alternatives locations. The probability of choosing location $j$ is:

$$
P_{j} \equiv \operatorname{Prob}\left(\pi_{j}>\pi_{k}\right)=\operatorname{Prob}\left(\epsilon_{k}<\epsilon_{j}+b\left(X_{j}-X_{k}\right)\right), \forall k \neq j
$$

If errors terms are independently and identically distributed according to a type I extreme-value distribution, the probability of choosing location $j$ writes:

$$
P_{j}=\frac{e^{b X_{j}}}{\sum_{i=1}^{n} e^{b X_{i}}} .
$$

In this conditional logit model (CLM) introduced by McFadden (1984), coefficients are estimated by maximum likelihood procedures.

8. However, results of several empirical analyzes suggest that such incentives have a weak effect (Wheeler and Mody, 1992, Crozet et al., 2003), even negative (Ferrer, 1998). 
The functional form of the CLM offers a number of advantages notably in terms of computational feasibility when the number of alternatives is high. A feature of the logit that can prove very convenient is the Independence of Irrelevant Alternatives (IIA), which is apparent when considering the odds ratio of alternative $j$ being chosen over alternative $i$ : This ratio $\left(P_{j} / P_{i}\right)$ depends only on the characteristics of the two alternatives and not on any other third choice.

However convenient this may be for some applications, IIA also implies that the error terms should be no more correlated within a subsample of the choice set than across subsamples. Stated differently, all alternatives should be comparable in terms of substitution patterns. This assumption has all chances to be violated in our case. Location choices of investors are very likely to have a nested structure. A decision tree that seems plausible is that investors would choose a region within Europe (East or West Europe), and then a country belonging to this region. Schematically, this can be represented as a decision tree in which the higher level of the tree consists of the two European regions (East and West), and the lower level of the countries belonging to each region. Note that upper and lower level decisions are not independent. Besides the attributes of each region, the characteristics of all the countries located in each region are considered by investors for the regional choice. The choice of the country is also conditional to the choice of the region, which takes place before. The nested logit model (NLM) ${ }^{9}$ allows for such a structure of location choice. We use this model to estimate the relevance of an East-West structure in the location choices of French firms in Europe.

Suppose $I=(1, \ldots, i, \ldots, l)$, the possible location regions and $J=\left(1, \ldots, j, \ldots, n_{i}\right)$, the countries belonging to the region $i$.

Location in a country $j$ belonging to the region $i$ offers a profit $\pi_{i j}$ :

$$
\pi_{i j}=V_{i j}+\epsilon_{i j}
$$

where

$$
V_{i j}=b X_{i j}+a Y_{i}
$$

With $V_{i j}$ a function of observable characteristics of location $j$. Unlike the previous model, these characteristics include characteristics which vary across regions and countries $\left(X_{i j}\right)$ on the one hand, and characteristics which vary across regions only $\left(Y_{i}\right)$ on the other hand. The probability of choosing region $i$ depends on characteristics of this region and on characteristics of all the countries belonging to this region, and is defined as follows:

$$
P_{i}=\frac{e^{a Y_{i}+\sigma_{i} I_{i}}}{\sum_{m=1}^{l} e^{a Y_{m}+\sigma_{m} I_{m}}}
$$

With $I_{i} \equiv \ln \left(\sum_{k \in i} e^{b X_{i k}}\right)$, the inclusive value representing the maximal utility expected from the choice of region $i$. This inclusive value depends on characteristics of all the countries located in region $i$. In the second step, the probability of choosing country $j$ conditional on the choice of region $i$ is:

$$
P_{j \mid i}=\frac{e^{b X_{i j}}}{\sum_{k=1}^{n_{i}} e^{b X_{i k}}}
$$

The probability of choosing country $j$ is given by:

9. See Maddala (1983) for a full description of this model. 


$$
P_{i j}=P_{j \mid i} \times P_{i}=\frac{e^{b X_{i j}}}{e^{I_{i}}} \times \frac{e^{a Y_{i}+\sigma_{i} I_{i}}}{\sum_{m=1}^{l} e^{a Y_{m}+\sigma_{m} I_{m}}} .
$$

If the coefficient on the inclusive value $(\sigma)$ is estimated to be 1 , the nested logit collapses to the conditional logit model presented above, in which countries are considered equivalent substitutes by investors. If, on the contrary, $\sigma=0$ the upper nest is the only relevant decision in the location choice, which means that countries inside the region are perfect substitutes.

\section{DATA}

\subsection{The dependent variable: Location choice}

Our sample consists of 1843 location decisions of French firms in Europe over the period 1980-1999. Data come from the 2000 version of the database constructed by the Direction des Relations Economiques Extérieures (DREE) of the French Ministry of Finances. For each investment, the database reports in particular the year of investment and the chosen country. Details on construction of our database are given in appendix 1.

We have 19 potential host countries in the sample: 13 EU countries ${ }^{10}$ and 6 CEECs (Bulgaria ${ }^{11}$, Hungary, Poland, Romania, Slovenia and ex-Czechoslovakia). The unavailability of separated statistical series for Czech Republic and Slovakia before 1993 (year of the disintegration of the Czechoslovak Federation) leads us to consider these two countries in an aggregated way over the whole period.

Of these 1843 observations, 1569 include Western Europe as a location and 274 Eastern Europe. Figure 1 displays the cumulative distribution of location decisions of French multinational firms in Eastern and Western Europe. It is immediately apparent that FDI in Western countries is dominant over the whole period but that the rise of FDI in CEECs is an important phenomenon.

\subsection{The independent variables}

Data sources and expected signs of independent variables are summarized in table 1. Some descriptive statistics including correlation matrix are given in appendix 2.

- Agglomeration (NF): This variable is defined as the sum of one plus the cumulated number of French firms of the same industry located in the country the year before the location decision of a new firm (as first proposed by Head et al., 1995). This method assumes that the firm taking the decision takes its own investment into account in the anticipated level of agglomeration/dispersion forces in the country. As noted in the introduction, the expected effect of this variable is uncertain.

- Demand (GDP): GDP of the host country is chosen as a measure of the potential demand. A firm will have a greater incentive to locate in a country where local demand to be served is high. This is only relevant if the firm actually sells locally. If FDI is totally export oriented, local demand will have no impact.

10. Data is aggregated for Belgium and Luxembourg.

11. For Bulgaria, the analysis covers the period 1980-1997. 
FIG. 1 - Location decisions of French multinational firms in Europe

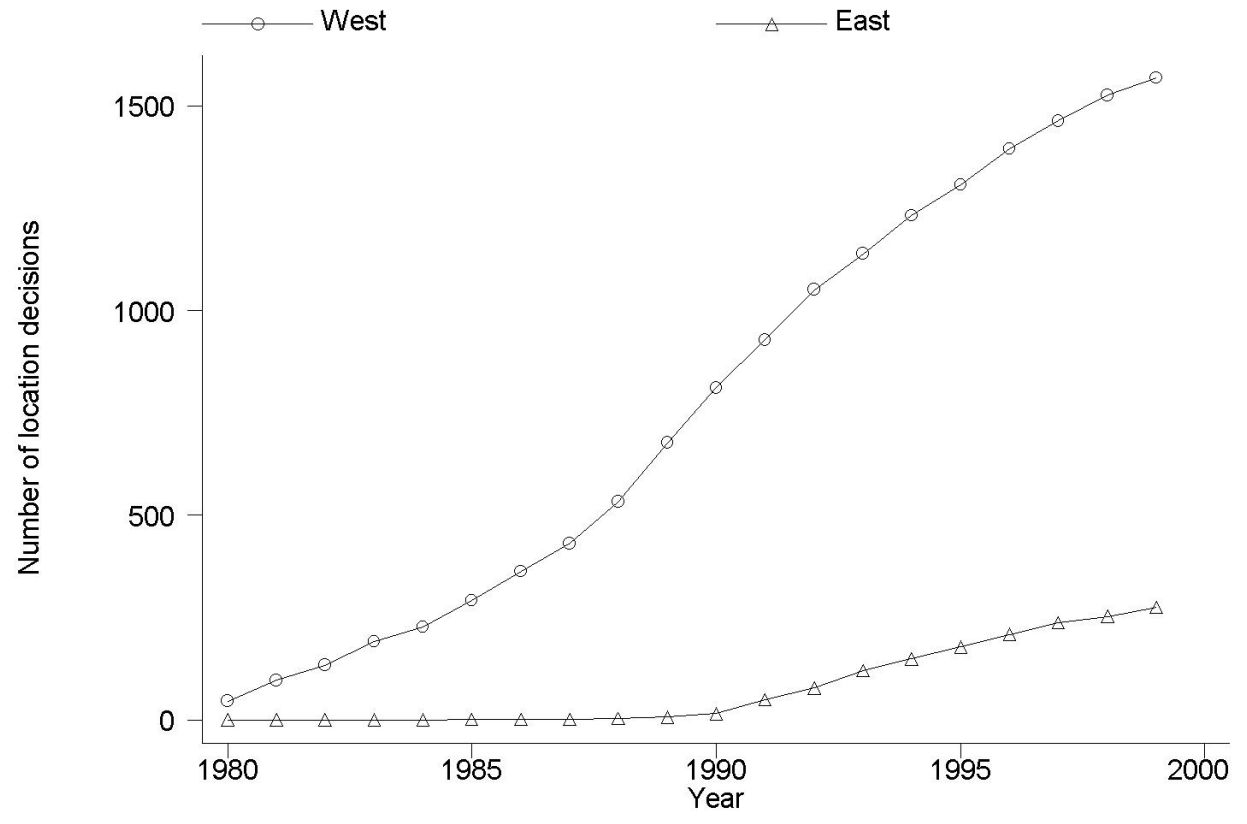


- GDP per capita (GDP/CAP): We also control for host country's development level. GDP per capita is used as proxy and we expect to find the probability of location to be positively correlated with this variable.

- Distance (DIST): Additionally, we control for the distance between France and host country. Distance is a proxy for transaction costs associated with every investment relation. The reasons for these costs can be information asymmetries, cultural differences, unfamiliarity with legal framework. Distance is drawn up as the sum of bilateral distances between capital cities of regions weighted by the economic size of the regions (the share of the population living in the region). This definition therefore takes into account the unequal distribution of the economic activity throughout the country. Bilateral distances between the regions centers of the countries are calculated using the great circle formula. The regional disaggregation of EU countries follows the NUTS Classification. We opt for the NUTS 1 level for all EU countries, except for Austria, Greece and Portugal. For these three countries, we chose NUTS 2 level. For CEECs, we refer to the statistical regions proposed by Eurostat on the pattern of NUTS Classification. Except for Poland, we chose NUTS 3 level. In case of Poland, the unavailability of a NUTS 3 disaggregation leads us to opt for the NUTS 2 level. A negative impact of distance is expected.

- Labor market: The labor costs proxies considered here are the average wage per capita (W) in manufacturing. Figure 2 plots the log of wage against the log of distance from France (see the description above); The "East/West gap" is particularly striking. A negative impact of labor costs on location decision is expected. Besides, we include a measure of unemployment (UNEMPL). The aim of this variable is to take into account large differences in the labor market institutions of the countries in the sample (Mayer and Mucchielli, 1999). Indeed, a high unemployment rate can be a signal of both availability of a large pool of workers (positive effect) and/or strong rigidities on the labor market (negative effect). However, note that involuntary unemployment is non-existent in CEECs during the socialist period; these countries even had a generalized shortage of labor force outside the firms. This shortage was combined with an excess of workers within the firms. This unavailability of labor force can be an obstacle to the location of foreign firms. So, the expected effect of unemployment is here ambiguous.

- Exchange rate volatility (EXCHR): In order to give some insights about the potential effects of CEECs participation to the European Monetary Union, we include a measure of exchange rate volatility and estimate its effect on location decisions. Recent papers have investigated the impact of a common currency and of exchange rate volatility on international trade, with interesting but controversial results (see Rose, 2000, Persson, 2001, Rose, 2001). We measure exchange rate volatility in country $i$ at time $t$ as the standard deviation of the first-difference of the monthly natural logarithm of the nominal exchange rate during the year $t$. Our approach is similar in spirit to the one adopted by Rose (2000) ${ }^{12}$, with some slight differences: Because of the strong economic changes that happened in CEECs during the period, the choice of the only year $t$ seems in our opinion to be more coherent. The impact of exchange rate volatility depends essentially on the risk aversion and the nature of the strategy of investors. Both being unknown, the effect of exchange rate volatility is undetermined ex ante.

12. The default measure of exchange rate volatility used by Rose (2000) is the following: Standard deviation of the first-difference of the monthly natural logarithm of the bilateral nominal exchange rate in the five years preceding year $t$ (Rose, 2000:15). 
FIG. 2 - Partial association between wage and distance from France

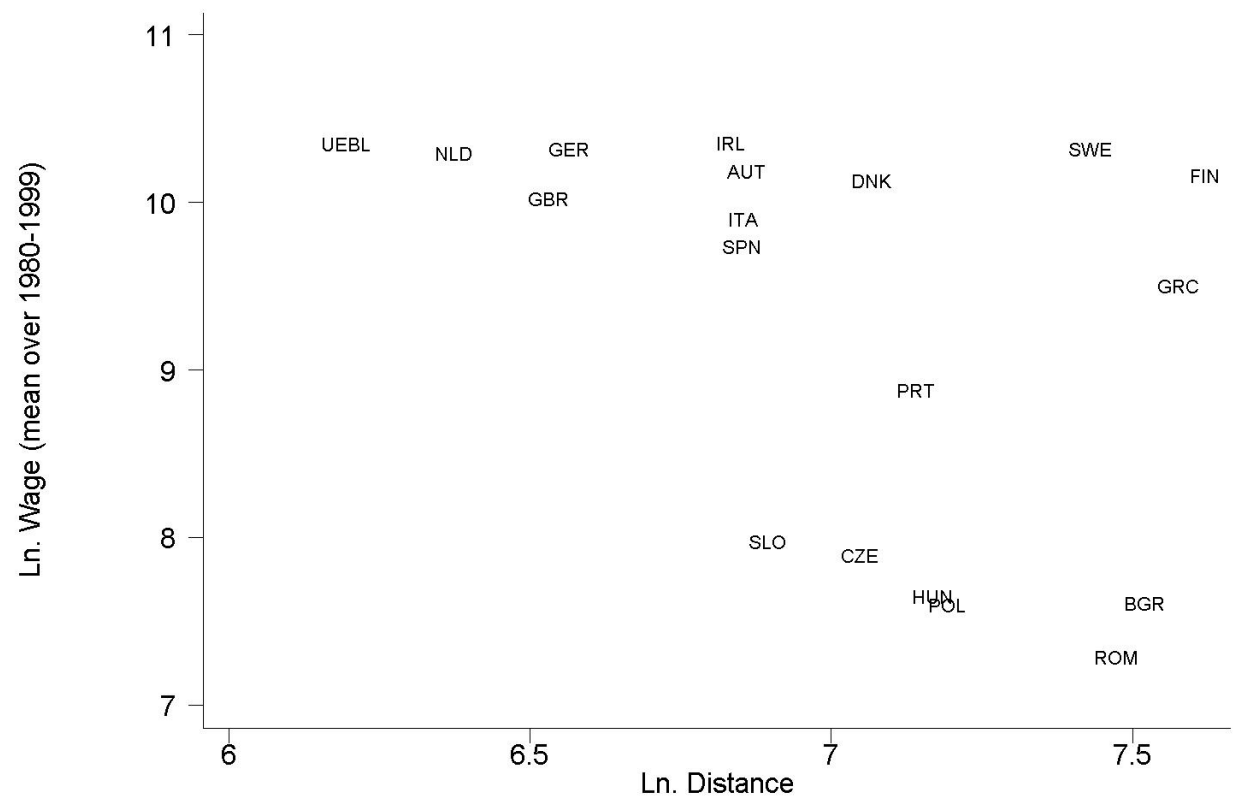


Besides these variables, several measures reflecting the institutional quality of each of the two parts of Europe are included. These variables underline an opposition between both regions and strengthen the relevance of an analysis of location choices following an East-West structure. Note that bad institutions are often considered as implicit taxation on the investor (think about the impact of corruption and property rights low levels of protection for instance).

- Institutions: Two recent studies analyze the effects of corruption in the host country on FDI. Using bilateral investment flows, Wei (2000) highlights a negative relation between corruption and FDI. Wei underlines that an increase in the corruption level from that of Singapore to that of Mexico would have the same effect on FDI as an increase of the tax rate from 18\% to 50\%. On the opposite, political stability affects positively FDI. The second analysis led by Smarzynska and Wei (2000), focuses on FDI in transition economies over the nineties and uses firm-level data. The aim of the paper is the study of the link between the extent of corruption in the host country and the choice of entry mode made by foreign investors. Results suggest that corruption encourages the formation of jointventures with a local partner. Having a local partner lowers the transaction cost. However, such a partnership generates a leakage of knowledge, and in particular of technological knowledge. Because of this leakage, firms with more sophisticated technologies are less inclined to share ownership and prefer a wholly-owned type of investment.

We use two different measurements in order to test for the influence of the institutional quality on location choices. The first one reports the degree of freedom existing in a country. By averaging two ratings (a first one for political rights, and a second one for civil liberties), Freedom House assigns each country to an overall status of "Free", "Partly Free", or "Not Free". These two last statuses are pooled in our estimations. This pool is validated by the likelihood-ratio test. Thus, two variables report the degree of freedom: FREE and PNFREE.

To confirm and develop the results obtained with this first measure, we also use the political rights rating constructed by Freedom House. The annual survey rates political rights on a scale going from 1 to 7,1 representing the best rating, and 7 the worst one. This polytomic variable is divided in seven categories. Each category is defined by a dummy. Categories 3, 4 and 5 on the one hand, and 6 and 7 on the other hand are pooled in the estimations. Again, this pool is validated by the likelihood-ratio test. Finally, the influence of political rights is measured by 4 variables PR1, PR2, PR345 and PR67. A high institutional quality strengthens the attractiveness of a country. The econometric interpretation of estimated coefficients on these institutional variables should be done comparatively to the reference variable. For example, suppose that PNFREE is the reference variable. A significant and positive coefficient on FREE suggests that a stronger degree of freedom influences positively the probability for a country to be chosen. In order to simplify, reference variables are always the variables representing the worst category in the estimations, namely PNFREE and PR67. Consequently, a positive sign is expected for FREE, PR1, PR2, and PR345.

We also test the sensitivity of our results for CEECs with respect to the measurement of institutional quality. Two indexes of economic liberalization are substituted for our measure of institutional quality: First, an annual liberalization index (LI), and second a cumulative liberalization index (CLI), defined as the sum of a country's LIs. Both are constructed by de Melo et al. (1997). LI is measured as a weighted average of internal markets liberalization, external markets liberalization, and private sector entry. Indexes are available over 1989-1994, and using EBRD indicators, an extension until 1999 is made (for a complete description, see de Melo et al., 1997). 


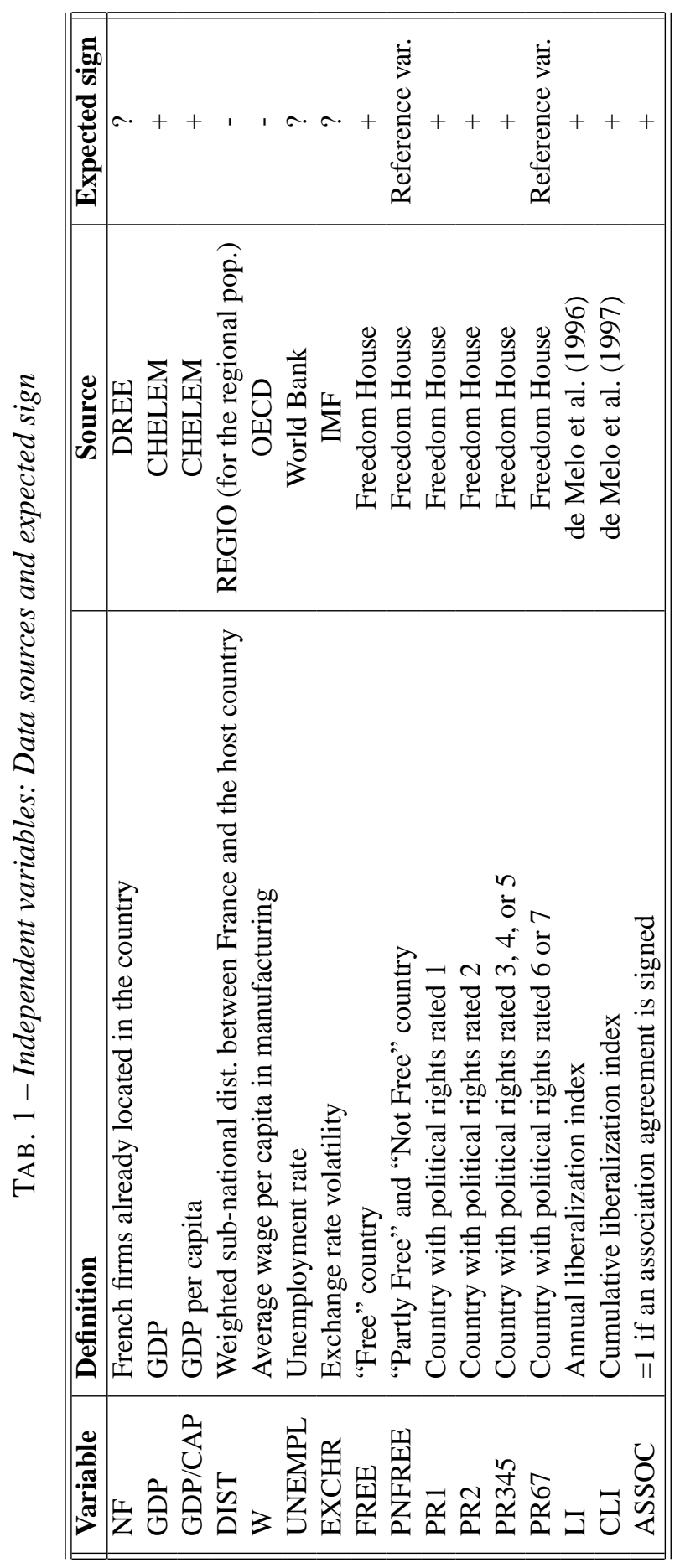




\section{RESUlts}

\subsection{Results of the estimations led with conditional logit model}

Table 2 summarizes the results concerning the determinants of location choice without taking into account a possible upper level tree structure (Eastern Europe - Western Europe) in the decision process. We begin with an estimation over the period 1980-1999 (columns 1 and 2). We then divide the sample into two sub-periods: 1980-1990 (columns 3 and 4), and 1991-1999 (columns 5 and 6). This division allows to highlight some changes in location decisions before and after the fall of the Communist Regime. The overall fit of the estimations is globally in line with the existing comparable papers using conditional logit techniques on location choices. The different determinants have in general the expected and accepted signs and magnitudes. All continuous variables are taken in logs, which enables to consider the coefficients to be quite precise approximations of the elasticity of the probability of choosing a particular country with respect to the considered variable for the average investor ${ }^{13}$.

Location choice is positively influenced by local demand. Besides, the greater is the distance between the French investor and the host country, the smaller is the probability for the country to be chosen. The results also reveal presence of agglomeration effects, the location of French competitors exercising a consistently positive and very significant impact on the attractiveness of potential host countries. This result is reminiscent of preceding work describing overall location patterns of French firms in EU countries at a regional level (Ferrer, 1998). Such a phenomenon is also true for location decisions of American firms (Wheeler and Mody, 1992, Devereux and Griffith, 1998), or Japanese firms (Head et al., 1995, Mayer and Mucchielli, 1999). These effects tend to give strength to the argument of positive non pecuniary externalities (technological or informational spillovers for instance) sufficiently important to more than offset the adverse competitive effect of spatial clustering on firms' profits. A country experiencing a $10 \%$ rise in the number of local French affiliates in the same industry increases its probability of being chosen in the future by 4.5 $-4.9 \%$.

The labor cost variable has a negative and significant influence on location choice over the second subperiod and imperfections of the labor market that might be captured through differences in unemployment rates do not seem to reduce the attractiveness of a country. Exchange rate volatility has a negative effect and this effect is significant over the second sub-period. This effect is relatively strong and clearly higher than the one obtained for trade flows (see Rose, 2000 for instance). Rose's estimated coefficient on exchange rate volatility is of -0.017 . Rose (2000) central investigation is the effect of common currency on trade. The effect of monetary unions is much larger than the effect of exchange rate volatility: Trade is multiplied roughly three-fold in this paper. Frankel and Rose (2000) and Rose and van Wincoop (2001) find similar results ${ }^{14}$. Bénassy-Quéré et al. (2001) study the effect of volatility on FDI ${ }^{15}$. Using a sample of 42 developing countries receiving FDI from 17 OECD countries over the period 1984-1996, the authors show that volatility reduce FDI. Besides, this effect is higher when host and investor countries are close.

13. The coefficient is all the more closer to this elasticity that the number of alternatives $N$ in the choice is large (the elasticity for the average investor can be shown to be equal to the coefficient times $(N-1) / N)$.

14. When multilateral resistance effects are included, results are however significantly reduced, but remain large (Rose and van Wincoop, 2001).

15. Volatility is measured by Bénassy-Quéré et al. (2001) as follows: coefficient of variation of the quarterly nominal exchange rate of the host country against the investing country over the past three years. 
TAB. 2 - Location choice of French firms in Europe - Whole sample - Estimations led with conditional logit model

\begin{tabular}{|c|c|c|c|c|c|c|}
\hline \multirow[b]{2}{*}{ Model : } & \multicolumn{6}{|c|}{ Dep. Variable: Location choice } \\
\hline & (1) & (2) & (3) & (4) & (5) & (6) \\
\hline \multirow[t]{2}{*}{ Ln Nb. French firms (NF) } & $0.46^{a}$ & $0.45^{a}$ & $0.46^{a}$ & $0.45^{a}$ & $0.49^{a}$ & $0.46^{a}$ \\
\hline & $(0.04)$ & $(0.04)$ & $(0.07)$ & $(0.07)$ & $(0.05)$ & $(0.05)$ \\
\hline \multirow[t]{2}{*}{ Ln GDP (GDP) } & $0.35^{a}$ & $0.35^{a}$ & $0.35^{a}$ & $0.35^{a}$ & $0.36^{a}$ & $0.38^{a}$ \\
\hline & $(0.03)$ & $(0.03)$ & $(0.04)$ & $(0.04)$ & $(0.04)$ & $(0.04)$ \\
\hline \multirow[t]{2}{*}{ Ln GDP per capita (GDP/CAP) } & $-0.34^{b}$ & $-0.44^{b}$ & $-0.70^{a}$ & $-0.77^{a}$ & 0.17 & -0.08 \\
\hline & $(0.15)$ & $(0.18)$ & $(0.22)$ & $(0.24)$ & $(0.26)$ & $(0.29)$ \\
\hline \multirow[t]{2}{*}{ Ln Distance (DIST) } & $-0.88^{a}$ & $-0.89^{a}$ & $-0.84^{a}$ & $-0.83^{a}$ & $-0.74^{a}$ & $-0.78^{a}$ \\
\hline & $(0.09)$ & $(0.10)$ & $(0.14)$ & $(0.14)$ & $(0.14)$ & $(0.14)$ \\
\hline \multirow[t]{2}{*}{ Ln Wage (W) } & $-0.33^{a}$ & $-0.36^{a}$ & -0.05 & -0.09 & $-0.71^{a}$ & $-0.62^{a}$ \\
\hline & $(0.11)$ & $(0.13)$ & $(0.17)$ & $(0.18)$ & $(0.20)$ & $(0.20)$ \\
\hline \multirow[t]{2}{*}{ Ln Unempl. (UNEMPL) } & $0.37^{a}$ & $0.30^{a}$ & $0.60^{a}$ & $0.56^{a}$ & -0.01 & -0.05 \\
\hline & $(0.07)$ & $(0.07)$ & $(0.10)$ & $(0.11)$ & $(0.11)$ & $(0.11)$ \\
\hline \multirow[t]{2}{*}{ Exch. Rate Volat. (EXCHR) } & $-2.18^{b}$ & $-2.50^{b}$ & 2.65 & -2.03 & $-2.28^{b}$ & $-2.14^{c}$ \\
\hline & $(0.98)$ & $(1.08)$ & $(4.12)$ & (4.67) & $(1.10)$ & $(1.11)$ \\
\hline \multirow[t]{2}{*}{ Free Country (FREE) } & $1.83^{a}$ & & $2.09^{a}$ & & $0.84^{a}$ & \\
\hline & $(0.24)$ & & $(0.44)$ & & $(0.28)$ & \\
\hline P.-N. Free Count. (PNFREE) & Ref. var. & & Ref. var. & & Ref. var. & \\
\hline \multirow[t]{2}{*}{ PR. rated 1 (PR1) } & & $4.09^{a}$ & & $3.36^{a}$ & & $1.16^{a}$ \\
\hline & & $(0.73)$ & & $(0.76)$ & & $(0.31)$ \\
\hline \multirow[t]{2}{*}{ PR. rated 2 (PR2) } & & $3.55^{a}$ & & $2.81^{a}$ & & $0.76^{a}$ \\
\hline & & $(0.73)$ & & $(0.75)$ & & $(0.28)$ \\
\hline \multirow[t]{2}{*}{ PR. rated 3, 4, 5 (PR345) } & & $2.61^{a}$ & & $1.89^{b}$ & & \\
\hline & & $(0.75)$ & & $(0.84)$ & & \\
\hline PR. rated 6, 7 (PR67) & & Ref. var. & & Ref. var. & & \\
\hline Observations & 1843 & 1843 & 825 & 825 & 1018 & 1018 \\
\hline Pseudo $\mathrm{R}^{2}$ & 0.152 & 0.156 & 0.221 & 0.223 & 0.108 & 0.109 \\
\hline
\end{tabular}

Notes: Standard errors in parentheses with ${ }^{a},{ }^{b}$ and ${ }^{c}$ respectively denoting significance at the $1 \%, 5 \%$ and $10 \%$ level. Specifications 1 and 2 consider the evolution between 1980-1999, specifications 3 and 4 (respectively 5 and 6) consider the evolution between 1980-1990 (respectively between 1991-1999). 
The explanation suggested by the authors is the following: When the distance between the two potential partners is high, the costs associated with distance override the ones associated with volatility.

Contrary to expectations, income levels (GDP/CAP) have a negative impact on location choice. It is however clear from the correlation matrix in the appendix that "institutions variables" are correlated with income per capita. The estimated coefficients on both measures of institutional quality (degree of freedom and political rights) are significant and positive ${ }^{16}$. So, institutional quality is an important determinant of location choice. Over the whole period and the first sub-period, estimated coefficients are particularly large, and as expected, coefficient on PR1 is larger than the one on PR2, and coefficient on PR2 larger than the one on PR345. However, note that coefficients on PR1 and PR2 are relatively close. Furthermore, this influence tends to decrease over time, perhaps also reflecting a convergence in the levels of institutional quality between potential host countries.

These two last observations enable the formulation of some hypothesizes: An improvement of the institutional framework seems to be a sufficient signal for the foreign investors. A rating of 2 for political rights is not a obstacle to foreign investments. Nevertheless, the gap between the coefficients on PR2 and PR345 is large, suggesting that the quality level reached should be sufficiently high.

Estimations conducted on the whole sample do not allow to highlight possible differences in the regional influence of each determinant. In other words, is the influence of each determinant similar for the Eastern and Western parts of Europe? In order to answer to this question, we now estimate the determinants of location choice separately for CEECs on the one hand (table 3), and for EU countries on the other hand (table 4).

For CEECs, results of the estimation on the whole period are described in column (1). We then restrict our estimation to the second sub-period (columns 2 to 5). Because of an insufficient number of investments before 1991, we are not able to proceed to an estimation of the determinants of location choice from 1980 to 1990. Different measures of institutional quality are used: Political rights (columns 1, 2 and 3), annual liberalization index (column 4), and cumulative liberalization index (column 5). In order to analyze the effect of signing an association agreement with the EU, a dummy variable ASSOC is included in columns (3), (4), and (5). We refer to the date of signing. From this year onwards ${ }^{17}$, ASSOC takes a value of 1.

Concerning EU countries (table 4), the whole sample is considered in column (1); columns (2) (respectively 3) includes only investments from 1980 to 1990 (respectively from 1991 to 1999).

For the institutional quality, we now use only the political rights measure. For the whole period and the first sub-period, we pool the variables PR2, PR345, and PR67 in a dummy PRUE. A likelihood-ratio test validates this pool. PRUE is the reference variable. The estimation led over 1991-1999 does not include political rights rating. Indeed, to the extent that all these countries receive a rating of 1 over this period, this measure has no relevance here.

Results suggest several differences between these two regions of Europe concerning the determinants of location choice.

- GDP, which offers a measure of the potential demand, has a weaker influence for EU countries than

16. Any country receives a rating of 6 or 7 over the period 1991-1999. Therefore, PR345 is the reference variable in the estimation led over 1991-1999.

17. Concerning the year of the signing, we apply the following sharing rule: ASSOC $=1$ if the signing happens before the middle of the year and 0 if the signing is reached after. 
for CEECs. This is contradictory with the view that FDI in Eastern Europe is entirely driven by a search for production costs and re-exports to the EU. Local markets seems an important determinant in the recent rise of inward investment in those countries.

- Agglomeration effects are less strong in CEECs than in EU countries. At first glance, this result is surprising. Indeed, because of a weaker knowledge of markets of CEECs, one can think that a firm investing in a CEEC will try to benefit more from positive spillovers and therefore be more attracted by countries where French firms are already present. The weaker influence of agglomeration effects as determinants of location choice in CEECs could be explained by stronger competition between firms in these countries. This competition generates a dispersion of economic activities. Another interpretation could be found in forward and backward linkages. It may be that affiliates in CEECs rely heavily on intermediates produced in France or other EU countries. In that case, input/output linkages and associated externalities would be smaller than for investments in EU countries where a larger proportion of inputs can be purchased locally.

- The negative impact of distance is particularly strong for CEECs. This result tends to confirm that additional transaction costs, resulting from information asymmetries, cultural differences, etc., reduce the probability of a country being chosen by foreign investors.

- Labor market variables: Estimated coefficients on these variables are different according the studied region. For CEECs, and comparatively to EU countries, it is noteworthy that wage costs have a stronger negative influence on location choice. Thus, inside the group of CEECs, location decisions seem to be sensitive to production costs differentials.

Divergences appear also for estimated coefficients on the exchange rate volatility and institutional variables.

- Exchange rate volatility has no influence on location decisions within the group of CEECs. A reasonable conclusion seems to be that if a determinant related to exchange rate volatility is to be important, it would be more linked to an East/West choice than to a country choice inside the CEEC region.

- Quality of institutional framework, measured with the political rights rating constructed by Freedom House, has no influence on location choice in EU countries, whereas a positive and significant influence is obtained for the variable PR1 for CEECs. However, note that the effect is weaker than the one obtained on the whole sample (Table 2). Contrary to expectations, the estimated coefficient on the annual liberalization index (LI) is not significant and the one on the cumulative liberalization index (CLI) is negative and significant at the $10 \%$ level. One possible explanation could be the existing correlation between these variables and some other explanatory variables. 
TАВ. 3 - Location choice of French firms in CEECs - Estimations led with conditional logit model

\begin{tabular}{|c|c|c|c|c|c|}
\hline \multirow[b]{2}{*}{ Model : } & \multicolumn{5}{|c|}{ Dep. Variable: Location choice } \\
\hline & (1) & (2) & (3) & (4) & (5) \\
\hline \multirow[t]{2}{*}{ Ln Nb. French firms (NF) } & $0.50^{a}$ & $0.38^{a}$ & $0.35^{a}$ & $0.38^{a}$ & $0.39^{a}$ \\
\hline & $(0.10)$ & $(0.11)$ & $(0.11)$ & $(0.11)$ & $(0.11)$ \\
\hline \multirow[t]{2}{*}{ Ln GDP (GDP) } & $0.46^{a}$ & $0.55^{a}$ & $0.37^{b}$ & $0.47^{a}$ & $0.50^{a}$ \\
\hline & $(0.14)$ & $(0.16)$ & $(0.17)$ & $(0.17)$ & $(0.16)$ \\
\hline \multirow[t]{2}{*}{ Ln GDP per capita (GDP/CAP) } & $-1.33^{b}$ & -1.25 & $-1.89^{b}$ & -1.00 & -0.58 \\
\hline & $(0.66)$ & $(0.82)$ & $(0.87)$ & $(0.69)$ & $(0.74)$ \\
\hline \multirow[t]{2}{*}{ Ln Distance (DIST) } & $-4.65^{a}$ & $-7.01^{a}$ & $-7.64^{a}$ & $-7.24^{a}$ & $-7.06^{a}$ \\
\hline & $(1.24)$ & $(1.48)$ & $(1.50)$ & $(1.62)$ & $(1.45)$ \\
\hline \multirow[t]{2}{*}{ Ln Wage (W) } & -0.47 & $-1.31^{b}$ & -0.91 & $-1.24^{b}$ & $-1.06^{b}$ \\
\hline & $(0.45)$ & $(0.60)$ & $(0.61)$ & $(0.57)$ & $(0.54)$ \\
\hline \multirow[t]{2}{*}{ Ln Unempl. (UNEMPL) } & $-0.71^{b}$ & -0.50 & -0.42 & -0.27 & 0.32 \\
\hline & $(0.28)$ & $(0.36)$ & $(0.35)$ & $(0.36)$ & $(0.46)$ \\
\hline \multirow[t]{2}{*}{ Exch. Rate Volat. (EXCHR) } & -1.59 & -0.36 & -0.90 & 0.09 & -0.89 \\
\hline & $(1.35)$ & $(1.36)$ & $(1.37)$ & $(1.36)$ & $(1.46)$ \\
\hline \multirow[t]{2}{*}{ PR. rated 1 (PR1) } & $1.65^{c}$ & $1.09^{b}$ & $1.01^{c}$ & & \\
\hline & $(0.99)$ & $(0.55)$ & $(0.54)$ & & \\
\hline \multirow[t]{2}{*}{ PR. rated 2 (PR2) } & 1.18 & 0.56 & 0.27 & & \\
\hline & $(0.93)$ & $(0.38)$ & $(0.39)$ & & \\
\hline PR. rated 3, 4, 5 (PR345) & $\begin{array}{c}0.84 \\
(0.88)\end{array}$ & Ref. var. & Ref. var. & & \\
\hline PR. rated 6, 7 (PR67) & Ref. var. & & & & \\
\hline \multirow[t]{2}{*}{ Ln Liberalization Index (LI) } & & & & 0.70 & \\
\hline & & & & $(1.02)$ & \\
\hline \multirow[t]{2}{*}{ Ln Cumulative Lib. Index (CLI) } & & & & & $-1.03^{c}$ \\
\hline & & & & & $(0.62)$ \\
\hline \multirow[t]{2}{*}{ Assoc. Agreement (ASSOC) } & & & $1.12^{b}$ & 0.74 & $1.13^{b}$ \\
\hline & & & $(0.54)$ & $(0.55)$ & $(0.52)$ \\
\hline Observations & 274 & 260 & 260 & 260 & 260 \\
\hline Pseudo $\mathrm{R}^{2}$ & 0.222 & 0.25 & 0.255 & 0.25 & 0.253 \\
\hline
\end{tabular}

Notes: Standard errors in parentheses with ${ }^{a},{ }^{b}$ and ${ }^{c}$ respectively denoting significance at the $1 \%, 5 \%$ and $10 \%$ level. Specification 1 considers the evolution between 1980-1999; specifications 2, 3, 4 , and 5 consider the evolution between 1991-1999. 
TAB. 4 - Location choice of French firms in EU - Estimations led with conditional logit model

\begin{tabular}{||l|ccc||}
\hline \hline \multirow{3}{*}{ Model : } & \multicolumn{3}{|c||}{ Dep. Variable: Location choice } \\
\cline { 2 - 4 } & $(1)$ & $(2)$ & $(3)$ \\
\hline Ln Nb. French firms (NF) & $0.52^{a}$ & $0.47^{a}$ & $0.62^{a}$ \\
Ln GDP (GDP) & $(0.05)$ & $(0.08)$ & $(0.08)$ \\
Ln GDP per capita (GDP/CAP) & $0.34^{a}$ & $0.37^{a}$ & $0.32^{a}$ \\
& $(0.03)$ & $(0.04)$ & $(0.05)$ \\
Ln Distance (DIST) & $-0.56^{a}$ & $-0.73^{a}$ & -0.39 \\
& $(0.21)$ & $(0.27)$ & $(0.36)$ \\
Ln Wage (W) & $-0.96^{a}$ & $-1.10^{a}$ & $-0.73^{a}$ \\
& $(0.11)$ & $(0.16)$ & $(0.18)$ \\
Ln Unempl. (UNEMPL) & $-0.52^{a}$ & $-0.43^{c}$ & $-0.58^{b}$ \\
& $(0.17)$ & $(0.23)$ & $(0.28)$ \\
Exch. Rate Volat. (EXCHR) & $0.28^{a}$ & $0.48^{a}$ & -0.01 \\
& $(0.08)$ & $(0.11)$ & $(0.13)$ \\
PR. rated 1 (PR1) & 4.50 & -7.33 & $19.29^{a}$ \\
& $(5.00)$ & $(7.18)$ & $(7.41)$ \\
PR. rated from 2 to 7 (PRUE) & 0.17 & 0.21 & \\
& $(0.21)$ & $(0.22)$ & \\
\hline Observations & Ref. var. & Ref. var. & \\
Pseudo R & & & \\
\hline \hline
\end{tabular}

Notes: Standard errors in parentheses with ${ }^{a}$ and ${ }^{b}$ respectively denoting significance at the $1 \%$ and $5 \%$ level. Specification 1 considers the evolution between 1980-1999; specification 2 (respectively 3) considers the evolution between 1980-1990 (respectively between 1991-1999). 
These estimations underline divergences in the determinants of location choice of French Firms in Eastern and Western Europe. In order to confirm the geographic structure of this choice, we now proceed to regressions using nested logit model.

\subsection{Results of nested logit estimations}

Table 5 presents the results. Because of the lack of data for Bulgaria after 1997, estimations do not include this country. The period 1991-1999 is included in columns (1) and (2). We then consider the three following sub-periods: 1991-1993 (column 3), 1994-1995 (column 4), and 1996-1999 (column 5). In the first column, a measure of the institutional quality is included. Because most of the countries are "FREE" over the period 1991-1999, this variable is then dropped.

At the regional (supra-national) level, the whole information relevant to choose between Eastern and Western Europe is included in the inclusive value. Indeed, as emphasized above, the inclusive value for each region contains all relevant attributes of the countries that belong to the considered region. We cannot identify any relevant attribute that would vary among regions but would be constant across countries in each region.

Concerning the coefficients on the inclusive value, first note that it is consistently estimated to be between 0 and 1 . This result confirms the relevance of an East-West structure in the country location choice of French multinational firms in Europe. In other words, it shows that the competition between countries in attracting foreign investors takes place more within the group of CEECs on one hand, and within the group of EU countries on the other hand than between CEECs and EU countries. Second, if we consider models (3), (4) and (5), we note that the inclusive value increases from 1991 to 1999. An increase in this coefficient means that the East-West tree structure is less and less relevant, i.e. that CEECs are becoming closer substitutes to EU countries. We find evidence of a growth in the coefficient on the inclusive value, and the difference between the estimated coefficient for the first and last sub-periods (1991-1993 and 19961999 ) is significantly different from zero. This suggests an increased similarity of Eastern and Western Europe as host countries for FDI.

\section{Conclusion}

We focus in this paper on location choices of French firms in EU countries and CEECs over the period 19801999. Results of econometric estimations suggest that these choices are geographically nested: French firms first choose a region (Eastern or Western Europe), and then a country within the region chosen. Determinants of location in each of these two regions present several differences. Our empirical approach furnishes a statistic for the measure of the gap between CEECs and EU countries in the opinion of French investors. The measured gap tends to decrease over time, pointing to increasingly similar "substituability" of Eastern and Western European countries for foreign investors. Besides, this decrease is statistically significant over the period considered.

One possible extension of this work would be to study if these findings are confirmed when another source country is considered. It seems particularly interesting to look at location choices from investors originating from outside the EU. 
TAB. 5 - Location choice of French firms in Europe - Estimations led with nested logit model

\begin{tabular}{||l|ccccc||}
\hline \multirow{3}{*}{ Model : } & \multicolumn{5}{|c||}{ Dep. Variable: Location choice } \\
\cline { 2 - 7 } & $(1)$ & $(2)$ & $(3)$ & $(4)$ & $(5)$ \\
\hline Ln Nb. French firms (NF) & $0.68^{a}$ & $0.71^{a}$ & $0.62^{a}$ & $0.70^{a}$ & $0.83^{a}$ \\
& $(0.06)$ & $(0.06)$ & $(0.10)$ & $(0.13)$ & $(0.10)$ \\
Ln GDP (GDP) & $0.30^{a}$ & $0.29^{a}$ & $0.42^{a}$ & $0.24^{a}$ & $0.20^{a}$ \\
& $(0.04)$ & $(0.04)$ & $(0.07)$ & $(0.09)$ & $(0.08)$ \\
Ln Distance (DIST) & -0.10 & -0.13 & -0.65 & 1.05 & -0.18 \\
& $(0.29)$ & $(0.29)$ & $(0.51)$ & $(0.79)$ & $(0.43)$ \\
Ln Wage (W) & $-0.70^{a}$ & $-0.60^{a}$ & $-0.89^{a}$ & $-0.69^{b}$ & -0.13 \\
& $(0.17)$ & $(0.16)$ & $(0.24)$ & $(0.34)$ & $(0.30)$ \\
Ln Unempl. (UNEMPL) & $-0.68^{a}$ & $-0.51^{b}$ & -0.57 & -0.88 & -0.33 \\
& $(0.25)$ & $(0.24)$ & $(0.40)$ & $(0.67)$ & $(0.36)$ \\
Exch. Rate Volat. (EXCHR) & -0.06 & -0.06 & -0.16 & 0.35 & -0.17 \\
& $(0.11)$ & $(0.11)$ & $(0.17)$ & $(0.29)$ & $(0.19)$ \\
Free Country (FREE) & -1.81 & $-4.79^{b}$ & $-6.00^{a}$ & -0.81 & $-13.68^{c}$ \\
& $(2.08)$ & $(2.00)$ & $(2.29)$ & $(16.66)$ & $(8.22)$ \\
P.-N. Free Count. (PNFREE) & $1.03^{a}$ & & & & \\
& $(0.32)$ & & & & \\
Inclusive Value & Ref. var. & & & & \\
& & & & & \\
\hline Observations & $0.91^{a}$ & $0.77^{a}$ & $0.47^{a}$ & $0.51^{a}$ & $0.92^{a}$ \\
Pseudo R ${ }^{2}$ & $(0.08)$ & $(0.06)$ & $(0.13)$ & $(0.07)$ & $(0.12)$ \\
\hline \hline
\end{tabular}

Notes: Standard errors in parentheses with ${ }^{a},{ }^{b}$ and ${ }^{c}$ respectively denoting significance at the $1 \%, 5 \%$ and $10 \%$ level. Specifications 1 and 2 consider the evolution between 1991-1999; specification 3 considers the evolution between 1991-1993; specification 4 considers the evolution between 1994-1995; specification 5 considers the evolution between 1996-1999. 


\section{REFERENCES}

BALDWIN, R., 1994, Towards an Integrated Europe, London: CEPR.

BÉNASSY-Quéré, A., L. Fontagné AND A. LAHRÈChE-RÉVIL, 2001, "Exchange-Rate Strategies in the Competition for Attracting Foreign Direct Investment", Journal of the Japanese and International Economies, 15: 178-198.

Bevans, A. AND E. Estrin, 2000, "The Determinants of Foreign Direct Investment in Transition Economies", WDI, Working Paper \# 342.

BRAINARD, S.L., 1993, "A Simple Theory of Multinational Corporations and Trade with a Trade-off between Proximity and Concentration." National Bureau of Economic Research Working Paper \# 4269

CEPR, 2002, Who's Afraid of the Big Enlargement?, London: CEPR.

Crozet, M., T. Mayer And J.-L. Mucchielli, 2003, "How do Firms Agglomerate? A Study of FDI in France", Regional Science and Urban Economics, forthcoming.

De Melo, M., C. Denizer And A. Gelb, 1997, "From Plan to Market - Patterns of Transition", in M. L. Blejer and M. Skreb (eds), Macroeconomic stabilization in transition economies, Cambridge University Press.

DeVereux, M. P. AND R. GRIFfith, 1998, "Taxes and the location of production: Evidence from a panel of US multinationals", Journal of Public Economics, 68: 335-367.

FERRER, C., 1998, "Patterns and Determinants of Location Decisions by French Multinationals in European Regions", in J.-L. Mucchielli (ed), Multinational Location Strategy, Greenwich: JAI Press.

FontAGNÉ, L. AND M. PAJOT, 1999, "Le potentiel d'échanges entre l'Union européenne et les PECO", Revue Economique, 50(6): 1139-68.

Frankel, J. A. AND A. K. Rose, 2000, "Estimating the Effect of Currency Unions on Trade and Output", NBER, Working Paper \# 7857.

Fujita, M., P. Krugman And A. Venables, 1999, The Spatial Economy: cities, regions, and international trade, MIT Press.

FUJITA, M. AND J.-F. THISSE, 2002, Economics of agglomeration: Cities, Industrial Location and Regional Growth, Cambridge University Press.

Guimarães, P., O. Figueiredo And D. Woodward, 2000, Agglomeration and the Location of Foreign Direct Investment in Portugal, Journal of Urban Economics 47(1) : 115-135.

Hansen, E. R., 1987, "Industrial Location Choice in Sao Paulo, Brazil, a nested logit model", Regional Science and Urban Economics, 17(1): 89-108.

Head, K. And T. MaYer, 2002, "Market Potential and the Location of Japanese Investment in the European Union", CEPR, Discussion Paper \# 3455

HeAD, K. And J. Ries, 1996, "Inter-City Competition for Foreign Investment: Static and Dynamic Effects of China's Incentive Areas", Journal of Urban Economics, 40: 38-60.

Head, K., J. Ries And B. Swenson, 1999, “Attracting Foreign Manufacturing: Investment, Promotion and Agglomeration", Regional Science and Urban Economics, 29(2): 197-218.

HeAd, K., J. Ries AND B. Swenson, 1995, "Agglomeration benefits and location choice: Evidence from Japanese manufacturing investments in the United States", Journal of International Economics, 38: 223-247.

Krugman, P. R., 1991, Geography and Trade, Cambridge: MIT Press. 
LANKes, H.-P. AND A. Venables, 1996, "Foreign direct investment in economic transition: the changing pattern of investments", Economics of Transition, 4(2): 331-347.

MCFADDEn D., 1984, "Econometric Analysis of Qualitative Response Models", in Griliches Z. and M.D. Intriligator (eds), Handbook of Econometrics vol.2, Amsterdam: Elsevier/North-Holland.

MadDala G.S., 1983, Limited-Dependent and qualitative Variables in Econometrics, Cambridge University Press.

Markusen, J.R. And A.J. Venables, 1998, "Multinational Firms and the New Trade Theory" Journal of International Economics, 46(2):183-203.

MAYER, T. AND J.-L. MuCChIELli, 1999, "La localisation à l'étranger des entreprises multinationales: une approche d'économie géographique hiérarchisée appliquée aux entreprises japonaises en Europe", Economie et Statistique, 326-327: 159-167.

MeYer, K., 1995, "Foreign direct investment in the early years of economic transition: a survey", Economics of Transition, 3(3): 301-320.

NeARY, P., 2001, "Of Hype and Hyperbolas: Introducing the New Economic Geography." Journal of Economic Literature 39 : 536-561.

NILSON, L., 2000, "Trade Integration and the EU Economic Membership Criteria", European Journal of Political Economy, 16(4): 807-27.

Pennings, E. And C. Altomonte, 2003, "The Hazard Rate of Foreign Direct Investment in Transition Countries: a Direct Estimation of a Real Option Model", Paper presented at the CEPR Workshop "The Economic Geography of Europe: Measurement, Testing and Policy Simulations".

Persson, T., 2001, "Currency unions and trade: how large is the treatment effect", Economic Policy, 33: 435-448.

Rose, A. K., 2001, "Currency unions and trade: the effect is large”, Economic Policy, 33: 449-461.

Redding, S. AND A. J. Venables, 2000, "Economic Geography and International Inequality”, CEPR, Working Paper \# 2568.

Rose, A. K., 2000, "One money, one market: the effect of common currencies on trade", Economic Policy, 30: 9-45.

Rose, A. K. And E. VAN Wincoop, 2001, "National Money as a Barrier to International Trade: The Real Case for Currency Union”, American Economic Review, 91(2): 386-390.

SMARZYNSKA, B., 1999, "Composition of Foreign Direct Investment and Protection of Intellectual Property Rights in Transition Economies", CEPR, Working Paper \# 2228.

Smarzynska, B. AND S.-J. WeI, 2000, "Corruption and Composition of Foreign Direct Investment: Firm-Level Evidence", NBER, Working Paper \# 7969.

Venables, A., 1996, "Equilibrium Locations of Vertically Linked Industries", International Economic Review, 37(2): 341-359.

WEI, S.-J., 2000, "How taxing is corruption on internal investors?", The Review of Economics and Statistics, 82(1): 1-11.

WheEler, D. AND A. Mody, 1992, "International investment location decisions. The case of U.S. firms", Journal of International Economics, 33: 57-76. 


\section{APPENDiX 1: DATABASE CONSTRUCTION}

Location decisions of French firms in Europe over the period 1980-1999 are part of the 2000 version of the DREE database. This database reports information on foreign affiliates of French firms all over the world. The version of this database that we were able to use has a lot of missing information and seems to be unable to distinguish correctly between production oriented plants and sales offices. Affiliates recorded in DREE are however generally connected to a French firm identification number which enables matching with other available information.

We therefore used different databases constructed by the French Ministry of Industry in order to complete and "clean up" the database. For this procedure, we refer to the identification number of the firm. Two merges are conducted: between the DREE database and different versions of the annual survey of firms one the one hand, and different versions of the annual survey of Establishments on the other one. Then, offices of representation and firms that really do not seem to have any manufacturing activity are dropped. Our criteria is based on a comparison between employment of the affiliate and the average employment of production plants owned by the same firm on the French territory. We consider only affiliates where employment level is at least 5\% of average French employment. When French employment is unknown, we retain only units over 10 employees.

\section{APPENDix 2: DESCRIPTIVE STATISTICS}

TAB. 6 - Summary Statistics

\begin{tabular}{||l|cccc||}
\hline \hline Variable & Minimum & Maximum & Mean & Std. Deviation \\
\hline GDP (Billion USD) & 7.63 & 2458.26 & 263.50 & 419,27 \\
GDP/CAP (USD) & 863.31 & 34768.91 & 11729.41 & 8674.18 \\
Distance (km.) & 490.54 & 2040.11 & 1196.05 & 457.10 \\
Wage (USD) & 212.52 & 80185.22 & 17795.06 & 14744.29 \\
Unemployment (\%) & 0 & 24.17 & 7.65 & 5.14 \\
Exchange Rate Volatility & 0 & 0.61 & 0.03 & 0.05 \\
Free Country (FREE) & 0 & 1 & 0.82 & 0.38 \\
P.-N. Free Country (PNFREE) & 0 & 1 & 0.18 & 0.38 \\
PR rated 1 (PR1) & 0 & 1 & 0.71 & 0.46 \\
PR rated 2 (PR2) & 0 & 1 & 0.11 & 0.32 \\
PR rated 3, 4, 5 (PR345) & 0 & 1 & 0.05 & 0.21 \\
PR rated 6, 7 (PR67) & 0 & 1 & 0.13 & 0.34 \\
Liberalization Index & 0.36 & 0.95 & 0.79 & 0.13 \\
Cumulative Lib. Index & 0.46 & 9.32 & 4.56 & 2.35 \\
Assoc. Agreement (ASSOC) & 0 & 1 & 0.11 & 0.31 \\
\hline \hline
\end{tabular}


TAB. 7 - Summary Statistics by Country

\begin{tabular}{|c|c|c|c|c|c|c|}
\hline Country & $\begin{array}{c}\text { GDP } \\
\text { (billion USD) } \\
\text { Mean over } \\
\text { 1980-1999 }\end{array}$ & $\begin{array}{l}\text { GDP/CAP } \\
\text { (USD) } \\
\text { Mean over } \\
1980-1999\end{array}$ & $\begin{array}{l}\text { Avge. annual } \\
\text { wage } \\
\text { per capita in } \\
\text { Manufact. } \\
\text { (USD) } \\
\text { Mean over } \\
\text { 1980-1999 }\end{array}$ & $\begin{array}{l}\text { Dist. } \\
(\mathrm{Km})\end{array}$ & FREE & $\begin{array}{l}\text { Nb. of } \\
\text { Invest } \\
\text { ments }\end{array}$ \\
\hline $\mathbf{E U}$ & & & & & & 1569 \\
\hline Austria (AUT) & 144,8 & 18428,7 & 27767,2 & 953,8 & & 54 \\
\hline Belg. and Lux. (UEBL) & 185,7 & 17795,3 & 34228,5 & 490,5 & & 220 \\
\hline Denmark (DNK) & 117,9 & 22684,8 & 25732,1 & 1173,5 & & 42 \\
\hline Finland (FIN) & 94,3 & 18791,9 & 26684,4 & 2040,1 & & 21 \\
\hline France (FRA) & 1042,0 & 18323,7 & 28321,8 & & EU & \\
\hline Germany (GER) & 1447,3 & 18005,2 & 31205,8 & 709,8 & countries & 285 \\
\hline Greece (GRC) & 79,2 & 7730,9 & 14169,3 & 1949,6 & are "Free" & 16 \\
\hline Ireland (IRL) & 45,5 & 12663,5 & 31975,7 & 927,6 & over 1980- & 37 \\
\hline Italy (ITA) & 849,0 & 14897,3 & 20394,6 & 947,7 & 1999 & 181 \\
\hline Netherland (NLD) & 268,6 & 17778,4 & 29771,4 & 586,0 & & 41 \\
\hline Portugal (PRT) & 65,6 & 6609,5 & 8102,7 & 1261,0 & & 144 \\
\hline Spain (SPN) & 401,7 & 10325,0 & 17354,8 & 945,4 & & 316 \\
\hline Sweden (SWE) & 185,4 & 21522,3 & 31736,2 & 1687,3 & & 8 \\
\hline United Kingdom (GBR) & 871,3 & 15030,4 & 22691,5 & 685,8 & & 204 \\
\hline CEECs & & & & & & 274 \\
\hline Bulgaria (BGR) & 12,9 & 1484,3 & 2143,0 & 1843,0 & Since 1991 & 12 \\
\hline Hungary (HUN) & 32,7 & 3159,9 & 2131,3 & 1297,4 & Since 1990 & 38 \\
\hline Poland (POL) & 89,8 & 2366,6 & 2075,7 & 1329,0 & Since 1990 & 55 \\
\hline Romania (ROM) & 40,4 & 1777,7 & 1515,7 & 1760,7 & Since 1996 & 24 \\
\hline Slovenia (SLO) & 15,9 & 8059,0 & 5786,3 & 986,9 & Since 1991 & 7 \\
\hline Czechoslovakia (CZE) & 58,4 & 3748,1 & 2639,7 & 1149,8 & Since 1990 & 138 \\
\hline
\end{tabular}


TAB. 8 - Correlation matrix

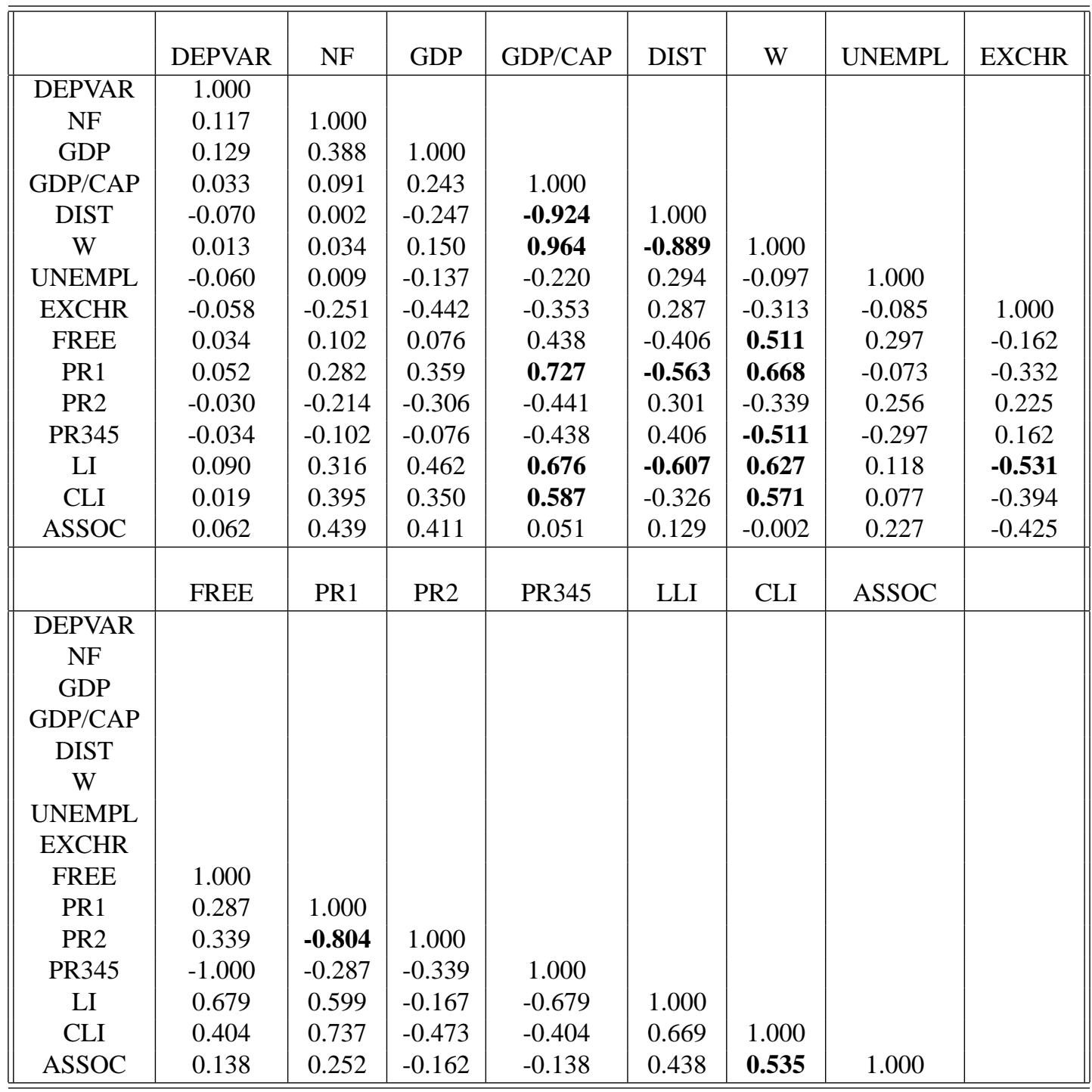

Note: Coefficients higher than 0.5 and relevant for our estimations are in bold. 